one of the greatest presidents the Society has ever had, should have reached the presidential chair. An interesting point that emerges from Dr. Mookerjee's address is that while official support was given to some aspects of science in India from as early a date as that of the birth of the Asiatic Society, the study of the cultural inheritance of India was left entirely to private non-official effort, both European and Indian, largely under the inspiration and encouragement of the Asiatic Society, until so late a date as 1860. In this year, during the time of Lord Canning, the first Viceroy of India, the Archæological Survey of Northern India was constituted, while in 1862 Cunningham was appointed archæological surveyor, to become later the first director-general of archæology in India. After Cunningham came a period of stagnation until Lord Curzon reconstituted the Archæological Department under Sir John Marshall. But the study of India's history as represented by ancient documents is still left to unofficial endeavour, organized mainly by the Asiatic Society, to which some official help is given in the form of annual grants towards the cost of study and publication.

Now that proposals are on foot for the expansion of scientific, medical and industrial research in India, the Asiatic Society, with its interests in all branches of learning-science and letters--does not propose to allow the cultural side of life to lag behind. For, as Dr. Mookerjee says, "neither can India attain her full strength and glory nor can she contribute worthily to the cause of stabilizing human civilization, if we ignore the need for a proper cultural reconstruction in India". The Council of the Society, working through an advisory body formed for the purpose, has in consequence submitted to the Government of India during 1944 proposals on (1) the establishment of a Travellers' Department in India ; (2) the necessity for a Central Record Office in Bengal; (3) the future development of the Archæological Department; (4) the establishment of a National Museum at New Delhi as a war memorial ; $(5)$ the amendment of the Ancient Monuments Preservation Act; (6) the establishment of a School of Architecture in India; (7) the necessity for a National Cultural Trust; (8) the establishment of a National Academy of Art and Letters ; (9) the constitution of national parks. These projects are for the future. As a useful activity for the present the Society has organized a series of discussion meetings to which invitations have been extended to all members of the Allied Forces in Calcutta. No less than thirty-nine meetings were held during 1944, addressed by a variety of lecturers on historical, literary, economic, industrial, and scientific subjects. The British and American military authorities co-operated in making these meetings a success, the one by a contribution towards the expenses, and the other by gifts of materials for providing refreshments. The Asiatic Society of Bengal proposes next year to celebrate the bi-centenary of the birth of its founder, Sir William Jones.

\section{Astronomy in France during the Occupation}

In the February issue of The Observatory $(66,23$; 1945), D. Chalonge gives a brief history of French astronomy and astronomers during the German occupation. Among the astronomers dismissed under the Vichy racial decrees-M. Lambert, director of the Bureau International de l'Heure, M. Mendès, M. Beloritzsky and Mlle. Bloch, assistants at the
Observatories of Bordeaux, Marseilles and Lyons respectively-all have been reinstated except M. Lambert, who was arrested in August 1943 and deported to Germany, and about whose safety there is anxiety. M. Mineur, director of the Institut d'Astrophysique, was several times imprisoned for political reasons. Removed by the Vichy Government from his post at the Observatory of Paris, he devoted much of his time to the resistance movement, and is now back with his former colleagues. M. Danjon, director of the Observatory of Strasbourg and dean of the Faculty of Science in the University, was also many times arrested by the Germans during the Gestapo campaign against the University, and was finally dismissed by the Vichy Government. Many astronomers were, however, allowed to work in the tranquillity of their observatories. In some cases this tranquillity covered patriotic activities, the observatories becoming meeting-places for the local resistance groups where pamphlets were printed and arms stored. Observatory buildings throughout France have come through the War unscathed, except perhaps those at Strasbourg, about which news is still lacking.

Development of the Service d'Astrophysique, founded in 1936, was interrupted by the outbreak of war. The Institut d'Astrophysique buildings in Paris were finished externally in 1940 when the Germans forbade further work, but this edict was clandestinely evaded with such success that workshops and laboratories were ready for use by January 1944. At the Observatory of Haute Provence, which forms part of the Service d'Astrophysique, many of the projected buildings were completed, and a 120-cm. telescope was brought into use a year ago. An $80-\mathrm{cm}$. telescope will shortly be installed in a dome already awaiting it. Work has continued on the Pic du Midi, where Lyot has carried on his researches on the solar corona outside eclipse and on planetary surface detail. Other researches published or to be published in the Annales d'Astrophysique include work on the night sky spectrum; photometric and spectrophotometric studies of lunar eclipses; investigations, observational and theoretical, on the continuous spectra of stars and diffuse nebulæ; observations of total hydrogen absorption in certain stellar spectra ; and a study of the monochromatic brightness across the sun's disk.

\section{Public Health in San Salvador}

AN article on this subject appears in the February issue of the Boletin de-la Oficina Sanitaria Panamericana by Dr. Manuel Zúnica Idiáquez, head of the Department of Health Education of the El Salvador Ministry of Health. San Salvador's publie health organization traces its origin to the Superior Board of Health at the beginning of this century, which was succeeded in 1920 by the National Department of Health. Since then much progress has been made as regards the preventive, rather than the curative, side of public health and the training of staff. The Rockefeller Foundation and the Pan-American Sanitary Bureau have been of great help, especially as regards the formation of a body of specialists in public health. At the present time valuable aid is also being received from the Co-operative InterAmerican Public Health Service, permitting the installation of safe water and sewage disposal systems, malaria control work, sanitary materials, public laundries and new buildings and health centres. 